\title{
KEWENANGAN APARAT KEPOLISIAN LALU LINTAS DALAM MELAKUKAN PENYITAAN BARANG BUKTI PELANGGARAN LALU LINTAS DI WILAYAH HUKUM POLRES PAYAKUMBUH.
}

\author{
ANA RAMADHONA \\ Sekolah Tinggi Ilmu Hukum Putri Maharaja Payakumbuh \\ ana.ramadhona84@gmail.com
}

\begin{abstract}
The exercise of authority in the form of confiscation actions carried out by members of the Payakumbuh City Police, especially traffic officers against vehicles that commit traffic violations, in taking action must be in accordance with Law Number 2 of 2002 concerning the Indonesian National Police, Law Number 22 of 2009 concerning Road Traffic and Transportation and the Criminal Procedure Code. Several inhibiting factors in confiscation of evidence in traffic include law enforcers who are often not firm in enforcing the rules, lack of facilities that support law enforcement such as the lack of traffic signs, the lack of police traffic vehicles in conducting patrols, and legal awareness that is less than adequate. There People must be able to understand traffic rules well. Regular socialization of traffic rules, firm action against traffic violators, addition of facilities and infrastructure for traffic signs can reduce traffic violations.
\end{abstract}

Keywords: Authority, Police, Confiscation, Evidence, Traffic Offenders.

\begin{abstract}
Abstrak: Pelaksanaan kewenangan berupa tindakan penyitaan yang dilakukan oleh anggota Kepolisian Resor Kota Payakumbuh khususnya petugas lalu lintas terhadap kendaraan yang melakukan pelanggaran Lalu Lintas, dalam melakukan penindakan harus sesuai dengan Undang-Undang Nomor 2 Tahun 2002 Tentang Kepolisian Republik Indonesia, UndangUndang Nomor 22 Tahun 2009 tentang Lalu Lintas dan Angkutan Jalan dan KUHAP. Beberapa faktor penghambat dalam penyitaan barang bukti dalam lalu lintas antara lain penegak hukum seringkali tidak tegas dalam menegakkan aturan, kurangnya sarana yang mendukung penegakan hukum seperti kurangnya rambu-rambu lalu lintas, minimnya kendaraan lalu lintas polisi dalam melakukan patroli, dan kesadaran hukum yang kurang dari masyarakat. Masyarakat harus bisa memahami peraturan lalu lintas dengan baik. Dilakukannya sosialisi aturan berlalu lintas secara berkala, tindakan tegas terhadap pelanggar lalu lintas, adanya penambahan sarana dan prasarana rambu-rambu lalu lintas bisa menekan pelanggaran lalu lintas .
\end{abstract}

Kata Kunci: Kewenangan, Kepolisian, Penyitaan, Barang Bukti, Pelanggran Lalu Lintas.

\section{A. Pendahuluan}

Pengertian dari Penegakan hukum adalah luas, mencakup kegiatan untuk melaksanakan dan menerapkan hukum serta melakukan tindakan hukum terhadap setiap pelanggaran hukum yang dilakukan oleh subjek hukum, baik melalui prosedur peradilan dan mekanisme penyelesaian sengketa lainnya (Jimly Asshiddiqie 2006:26). Dari definisi diatas dapat disimpulkan,penegakan hukum tidak hanya mencakup penegakan hukum atau "law enforcement", akan tetapi juga menjaga ketertiban atau "peace maintenance". Penegakan hukum yang adil terwujud, diperlukan organ organ dalam penegakannya yang mencakup mereka yang bertugas di bidang-bidang kehakiman, kejaksaan, kepengacaraan dan kepolisian. Penegak hukum di Indonesia yang salah satunya Kepolisian Republik Indonesia atau Polri yang memiliki unsur Criminal Justice System. Sebagai bagian dari penegak hukum dan terkait dalam penegakan hukum (selain jaksa, hakim dan pengacara), kepolisian bertindak harus sesuai dan berdasarkan peraturan perundangan yang berlaku. Prinsip inilah yang sesungguhnya melekat pada tugas penegakan hukum, termasuk oleh kepolisian (Alfons Loemeu, 2005:1)

Selaku penegak hukum tindakan yang dilakukan oleh kepolisian terkait dengan peraturan-peraturan Lalu Lintas dan angkutan jalan raya akan didasarkan pada kronologis 
penerbitan peraturan-peraturan tersebut. Hal ini akan memudahkan sistematisasi dan klasifikasinya menurut komponen-komponen pokok dari masalah Lalu Lintas dan angkutan jalan raya. Peraturan-peraturan yang dipilih adalah ketentuan-ketentuan yang hanya menyangkut kepentingan-kepentingan warga masyarakat pada umumnya. Artinya, tidak akan dijelaskan peraturan-peraturan yang tertuju pada golongan tertentu seperti pengusaha angkutan umum, pengusaha bengkel umum, petugas-petugas Lalu Lintas dan juga tidak akan disinggung peraturan-peraturan yang terlalu teknis sifatnya, umpamanya perihal izin trayek angkutan penumpang dan barang, perubahan rute arus Lalu Lintas, pemasangan rambu-rambu Lalu Lintas, tarif plat nomor dan tanda uji dan lain-lain (Soerjono Soekanto 1986:114).

Sesuai dengan uraian-uraian di atas maka perlu dikemukakan secara terperinci mengenai pokok-pokok peraturan-peraturan Lalu Lintas yang harus diketahui dan dipatuhi oleh warga masyarakat pada umumnya sepanjang mereka mempergunakan jalan tersebut. Warga-warga masyarakat diharapkan mengetahui dan patuh terhadap peraturan-peraturan tadi demi terciptanya keamanan, ketertiban dan kelancaran Lalu Lintas sebagai mana yang diatur dalam Undang-Undang Nomor 22 Tahun 2009 Tentang Lalu Lintas dan Angkutan Jalan, ditambah dengan Peraturan Pemerintah Nomor 80 Tahun 2012 Tentang Tata Cara Pemeriksaan Kendaraan Bermotor dan Penindakan Pelanggaran Lalu Lintas dan Angkutan Jalan. Khusus mengenai Lalu Lintas di jalan raya salah satu komponen yang terkait didalamnya adalah pihak kepolisian sebagai mana yang telah ditentukan oleh Undang-Undang Nomor 22 Tahun 2009 Tentang Lalu Lintas dan Angkutan Jalan. Undang-undang ini mengatur salah satu kewenangan Polri yaitu mengenai penyitaan. Penyitaan barang bukti yang dapat dilakukan oleh Polri antara lain diatur dalam Pasal 260 ayat (1).

Pasal 260 ayat (1) Dalam hal penindakan pelanggaran dan penyidikan Tindak Pidana, Penyidikan Kepolisian Negara Republik Indonesia selain yang diatur di dalam KUHAP, dan Undang-Undang Nomor 2 Tahun 2002 Tentang Kepolisian Negara Republik Indonesia, dan dibidang Lalu Lintas dan angkutan jalan berwenang antara lain memberhentikan, melarang menunda pengoperasian dan menyita sementara kendaraan bermotor yang patut di duga melanggar peraturan berlalu lintas atau merupakan alat dan atau hasil kejahatan, melakukan penyitaan terhadap Surat Izin Mengemudi (SIM), Kendaraan Bermotor, Muatan, Surat Tanda Nomor Kendaraan Bermotor (STNKB) dan tanda lulus uji sebagai barang bukti pelanggaran lalu lintas.

Peraturan ini berlaku bagi semua tingkatan baik Mabes Polri, Polda, Polres, dan Polsek dan termasuk juga daerah yang dijadikan objek penelitian penulis yakni Payakumbuh. Kepolisian dalam hal ini Polisi Lalu Lintas Resort Payakumbuh memiliki peran dalam penindakan pelanggaran Lalu Lintas di Kota Payakumbuh. Penindakan terhadap pelanggaran Lalu Lintas yang dapat dilakukan oleh kepolisian berdasarkan kewenangannya. Pemeriksaan kendaraan bermotor di jalan dilakukan oleh Petugas Polri meliputi pemeriksaan: 1) Surat Izin Mengemudi (SIM), surat tanda nomor kendaraanbermotor (STNKB), surat tanda coba kendaraan bermotor untuk kendaraan baru(STCKB); 2) Tanda bukti lulus uji bagi kendaraan wajib uji; 3) Fisik kendaraan bermotor; 4) Daya angkut danatau cara pengangkutan barang; 5) Izin penyelenggaraan angkutan.

Penyidik Kepolisian dalam hal penindakan pelanggaran dan penyidikan tindak pidana di bidang Lalu Lintas dan angkutan jalan berwenang; a) Memberhentikan, melarang, atau menunda pengoperasian dan menyita sementara kendaraan bermotor yang patut diduga melanggar peraturan berlalu lintas atau merupakan alat danatau hasil kejahatan; b) Melakukan pemeriksaan atas kebenaran keterangan berkaitan dengan penyidikan tindak pidana di bidang lalu lintas dan angkutan jalan; c) Meminta keterangan dari pengemudi, pemilik kendaraan bermotor, dan atau perusahaan angkutan umum; d) Melakukan penyitaan terhadap Surat Izin Mengemudi, kendaraan bermotor, muatan, surat tanda nomor kendaraan bermotor, surat kendaraan bermotor, dan/atau tanda lulus uji sebagai barang bukti; dan e) Melakukan penindakan terhadap tindak pidana pelanggaran atau kejahatan Lalu Lintas menurut ketentuan peraturan perundang- undangan. 
Namun disisi lain masyarakat dalam berlalu lintas dijalan raya sering melakukan perbuatan yang melanggar peraturan Lalu Lintas, baik yang disengaja maupun tidak disengaja bahkan tidak jarang berakhir dengan penilangan dan penyitaan barang bukti oleh aparat kepolisian akibat dari pelanggaran yang di lakukan pengemudi tersebut. Penyitaan barang bukti dalam Lalu Lintas yang dapat dilakukan oleh aparat kepolisian adalah apabila pengemudi kendaraan bermotor yang tidak mematuhi rambu-rambu jalan, tidak memiliki Surat Izin Mengemudi (SIM), melaju dengan kecepatan tinggi di jalan raya, tidak memiliki Surat Tanda Nomor Kendaraan Bermotor (STNKB), tidak memakai pengaman dan sebagainya.

Peranan institusi terkait yaitu aparat kepolisian dan kontrol sosial masyarakat sangat diperlukan sekali mengenai kesadaran hukum masyarakat dalam berlalu lintas. Salah satu upaya peningkatan kesadaran masyarakat dan disiplin masyarakat berlalu lintas dapat dilakukan dengan penyebarluasan pengetahuan hukum masyarakat khususnya dalam berlalu lintas di jalan raya. Sehingga tingkat pelanggaran berlalu lintas dapat ditekan terus atau dapat diantisipasi sedini mungkin, baik dari segi kualitas maupun kuantitasnya. Pelanggaran Lalu Lintas dalah masalah yang timbul di jalan umum yang melibatkan pemakai jalan yang sedang bergerak, baik itu kendaraan bermotor, orang, hal ini sesuai dengan bunyi Pasal 1 butir (1) Undang-Undang Nomor 22 Tahun 2009 Tentang Lalu Lintas dan Angkutan Jalan, yakni satu kesatuan sistem yang terdiri atas Lalu Lintas, angkutan jalan, jaringan Lalu Lintas dan angkutan jalan, prasarana Lalu Lintas, angkutan jalan, pengemudi, pengguna jalan serta pengelolaannya."

\section{B. Metodologi Penelitian}

Untuk memudahkan membahas setiap permasalahan dalam penulisan ini, maka disamping itu pengumpulan bahan dan data-data yang erat kaitannya dengan pokok bahasan atau permasalahan dalam penulisan ini, perlu dilakukan penelitian. Adapun metode yang dilakukan dalam penelitian ini adalah yuridis empiris yakni penelitian yang menguji efektifitas hukum dalam pelaksanaannya di lapangan.

\section{Hasil dan Pembahasan}

1. Pelaksanaan Kewenangan Aparat Kepolisian Dalam Melakukan Penyitaan Barang Bukti Pelanggaran Lalu Lintas Di wilayah Hukum Polres Payakumbuh

Berdasarkan hasil wawancara dengan Bapak AKP. Yulnaidi Chainir S.E.,M.H, Kasat Lantas Polres Payakumbuh terhadap kewenangan aparat kepolisian dalam melakukan penyitaan barang bukti pelanggaran Lalu Lintas di wilayah hukum Polres Payakumbuh dilandaskan pada Undang-Undang Nomor 22 Tahun 2009 Tentang Lalu Lintas dan Angkutan Jalan, Undang-Undang Nomor 2 Tahun 2002 Tentang Kepolisian Republik Indonesia dan KUHAP Pasal 39 (1).

Adapun pelaksanaan kewenangan aparat kepolisian dalam melakukan penyitaan barang bukti pelanggaran lalu lintas di wilayah hukum Polres Payakumbuh yaitu: 1) Setiap personil yang akan melaksanakan tugas dalam penertiban kendaraan harus dilengkapi surat perintah tugas dari pimpinan. Selain itu personil juga dilengkapi dengan beberapa atribut seragam seperti pluit, rompi baju, blanko tilang dan lain-lain untuk tanda penyitaan barang bukti. Banyaknya pelanggaran lalu lintas yang dilakukan oleh masyarakat menyebabkan polres Payakumbuh kekurangan personil, ini meyebabkan pelaksanaan penertiban kendaraan tidak bisa berjalan dengan maksimal; 2) Dalam melakukan penyitaan barang bukti pelanggaran, secara langsung dilakukan ditempat perkara seperti pemberhentian, kemudian pemeriksaan dan kalau terdapat pelanggaran maka dilakukan penyitaan terhadap surat-surat atau kendaraan si pelanggar. Penyitaan barang bukti pelanggaran terkadang terkendala dan pelakasanaannya tidak maksimal karena banyak diantara pelanggar tidak terima dengan pasal-pasal yang ditetapkan oleh petugas sehingga terkadang terjadi adu mulut antara petugas dan sipelanggar. Disamping itu banyak juga diantara pelangggar ini meminta untuk sidang ditempat, ini jelas bertentangan dengan aturan yang berlaku; 3) Personil yang melaksanakan tugas dalam penertiban kendaraan akan bertindak tegas terhadap para pelanggar yang berusaha untuk 
melarikan diri/ kabur saat razia sedang dilaksanakan karena itu dapat menyebabkan terjadinya kemacetan ataupun kecelakaan yang tidak hanya merugikan sipelanggar tetapi juga orang lain.

Kewenangan Aparat Kepolisian Dalam Melakukan Penyitaan Barang Bukti Pelanggaran Lalu Lintas Diwilayah Hukum Polres Payakumbuh, juga temuat Pasal 7 Peraturan Kapolri Nomor 23 Tahun 2010, satuan lalu lintas merupakan Unsur pelaksana tugas Pokok di tingkat Polres. Selanjutnya lebih ditegaskan pada Pasal 59 Peraturan Kapolri Nomor 23 Tahun 2010, dijelaskan bahwa Satlantas sebagaimana dijelaskan bahwa: 1) Satuan lalu lintas merupakan unsur pelaksana tugas pokok yang berada di bawah Kapolres; 2) Satlantas bertugas melaksanakan Turjawali lalu lintas, pendidikan masyarakat lalu lintas (Dikmaslantas), pelayanan registrasi dan identifikasi kendaraan bermotor dan pengemudi, penyidikan kecelakaan lalu lintas dan penegakan hukum di bidang lalu lintas; 3) Dalam melaksanakan tugas sebagaimana dimaksud pada ayat (2), Sat lantas menyelenggarakan fungsi: a) Pembinaan lalu lintas kepolisian; b) Pembinaan partisipasi masyarakat melalui kerja sama lintas sektoral, Dikmaslantas, dan pengkajian masalah di bidang lalu lintas; c) Pelaksanaan operasi kepolisian bidang lalu lintas dalam rangka penegakan hukum dan keamanan, keselamatan, ketertiban, kelancaran lalu lintas (Kamseltibcarlantas); d) Pelayanan administrasi registrasi dan identifikasi kendaraan bermotor serta pengemudi; e) Pelaksanaan patroli jalan raya dan penindakan pelanggaran serta penanganan kecelakaan lalu lintas dalam rangka penegakan hukum, serta menjamin Kamseltibcarlantas di jalan raya; f) Pengamanan dan penyelamatan masyarakat pengguna jalan; dan g) Perawatan dan pemeliharaan peralatan dan kendaraan.

Bentuk dan tata cara penyitaan Tata cara aparatur penegak hukum melaksanakan tugas dalam masyarakat baik itu merupakan tindakan pencegahan (preventif) maupun tindakan pemberantasan (represif), adalah merupakan ranah Hukum Acara Pidana yang mempunyai tujuan yaitu untuk mencari dan mendekatkan kebenaran materiil, yakni kebenaran yang selengkap-lengkapnya dari suatu perkara pidana dengan menetapkan ketentuan hukum acara pidana secara jujur dan tepat (Ratna Nurul Afiah :16).

Berdasarkan Pasal 16 ayat (1) Undang-Undang Nomor 2 Tahun 2002 Tentang Kepolisian Republik Indonesia dalam rangka menyelenggarakan tugas di bidang proses pidana, Kepolisian Negara Republik Indonesia berwenang untuk: a) Melakukan penangkapan, penahanan, penggeledahan, dan penyitaan; b) Melarang setiap orang meninggalkan atau memasuki tempat kejadian perkara untuk kepentingan penyidikan; c) membawa dan menghadapkan orang kepada penyidik dalam rangka penyidikan; d) Menyuruh berhenti orang yang dicurigai dan menanyakan serta memeriksa tanda pengenal diri; e) Melakukan pemeriksaan dan penyitaan surat; f) Memanggil orang untuk didengar dan diperiksa sebagai tersangka atau saksi; g) Mendatangkan orang ahli yang diperlukan dalam hubungannya dengan pemeriksaan perkara; h) Mengadakan penghentian penyidikan; i) Menyerahkan berkas perkara kepada penuntut umum; j) Mengajukan permintaan secara langsung kepada pejabat imigrasi yang berwenang di tempat pemeriksaan imigrasi dalam keadaan mendesak atau mendadak untuk mencegah atau menangkal orang yang disangka melakukan tindak pidana; k) Memberi petunjuk dan bantuan penyidikan kepada penyidik pegawai negeri sipil serta menerima hasil penyidikan penyidik pegawai negeri sipil untuk diserahkan kepada penuntut umum; dan 1 Mengadakan tindakan lain menurut hukum yang bertanggung jawab yang memenuhi syarat diantaranya tidak bertentangan dengan suatu aturan hukum; selaras dengan kewajiban hukum yang mengharuskan tindakan tersebut dilakukan; harus patut, masuk akal, dan termasuk dalam lingkungan jabatannya; pertimbangan yang layak berdasarkan keadaan yang memaksa; dan menghormati hak asasi manusia (HAM).

Dari penjelasan diatas dapat disimpulkan bahwa terhadap pelanggaran Lalu Lintas seperti tidak memakai helm, menerobos lampu merah, tidak membawa surat kelengkapan berkendaraan, Tidak menggunakan kaca spion, tidak menyalakan lampu kendaraan, melawan arus, dan pelanggaran Lalu lintas lainnya makaPolisi Lalu Lintas di wilayah Kepolisian Resort Payakumbuh berwenang melakukan penindakan dengan tilang,serta penyitaan terhadap surat kenderaan atau kendaraan bermotor itu sendiri yang berpedoman pada Undang-Undang

396 Lembaga Penelitian dan Penerbitan Hasil Penelitian Ensiklopedia $\quad$ E-ISSN: 2657-0300

P-ISSN: 2657-0319 
Nomor 22 Tahun 2009 tentang Lalu Lintas dan Angkutan Jalan Pasal 260 ayat (1) huruf d, Undang-Undang Nomor 2 Tahun 2002 Tentang Kepolisian Republik Indonesia Pasal 16 ayat (1) huruf a, KUHAP pasal 38 ayat 1,pasal 40, dan pasal 41 sebagai pedoman yang menyatakan boleh melakukan penyitaan terhadap kendaraan yang melanggar peraturan Lalu Lintas.

Lalu dihubungkan dengan kenyataan yang terjadi di wilayah Kepolisian Resort Payakumbuh melalui hasil penelitian yang peneliti lakukan, penulis menyimpulkan bahwa pelaksanaan kewenangan berupa tindakan penyitaan yang dilakukan oleh kepolisian berdasarkan wawancara yang dilakukan terhadap AKP. Yulnaidi Chainir sebagai kasat lantas, Ipda Eldrina Wati sebagai sebagai KBO Satlantas dan Musrizal sebagai Paur min Ops/ Baur Tilang terhadap tindakan penyitaan yang dilakukan terhadap kendaraan yang melakukan pelanggaran Lalu Lintas, petugas Lalu lintas dalam melakukan penindakan sesuai dengan Undang-Undang Nomor 2 Tahun 2002 Tentang Kepolisian Republik Indonesia Pasal 16 ayat (1) huruf a dan huruf e, Undang-Undang Nomor 22 Tahun 2009 tentang Lalu Lintas dan Angkutan Jalan Pasal 260 ayat (1) huruf d, dan Pasal 38 ayat (1) dan (2), Pasal 40 dan 39 ayat (1) KUHAP, serta Pasal 40 dan Pasal 41 KUHAP. Sehingga pelaksanaan kewenangan polisi Lalu Lintas secara nasional dihubungkan dengan pelaksanaan dilapangan terkhusus di Payakumbuh dilandasi terhadap peraturan yang berlaku

\section{Faktor Penghambat dalam Pelaksanan Kewenangan Aparat Kepolisian dalam Penyitaan Barang Bukti Pelanggaran Lalu Lintas di Wilayah Hukum Polres Payakumbuh}

Indonesia merupakan salah satu negara dengan jumlah kendaraan bermotor sangat tinggi tidak terkecuali Kota Payakumbuh. Akibat dari banyaknya kendaraan bermotor, seringkali terjadi kemacetan di Jalan. Kemacetan ini merupakan salah satu faktor yang menyebabkan terjadi pelanggaran terhadap Lalu Lintas. Pelanggaran Lalu Lintas yang tidak ditindak mengakibatkan perilaku pelanggar merasa tidak melakukan suatu kesalahan sehingga menjadi suatu kebiasaan. Tetapi banyak juga masyarakat tidak menerima apabila dilakukan penindakan, penyitaan oleh polisi dan pelanggar melakukan perlawanan yang mengakibatkan terkendalanya penyitaan barang bukti sehingga mengakibatkan polisi sulit melakukan penyitaan, berdasarkan kenyataan diatas, penulis membahas faktor-faktor penghambat dalam penyitaan barang bukti pelanggaran Lalu Lintas di wilayah Polres Payakumbuh.

Sebelum masuk ke bahasan pokok, penulis membahas kendala secara umum dalam penegakan hukum, faktor-faktor yang mempengaruhi penegakan hukum menurut Soerjono Soekanto adalah (Soerjono Soekanto, 2004:42)

1. Faktor Hukum. Praktik penyelenggaraan hukum di lapangan ada kalanya terjadi pertentanganantara kepastian hukum dan keadilan, hal ini disebabkan oleh konsepsi keadilan merupakan suatu rumusan yang bersifat abstrak, sedangkan kepastian hukum merupakan suatu prosedur yang telah ditentukan secara normatif. Justru itu, suatu kebijakan atau tindakan yang tidak sepenuhnya berdasar hukum merupakan sesuatu yang dapat dibenarkan sepanjang kebijakan atau tindakan itu tidak bertentangan dengan hukum. Maka pada hakikatnya penyelenggaraan hukum bukan hanya mencakup law enforcement, namun juga peace maintenance, karena penyelenggaraan hukum sesungguhnya merupakan proses penyerasian antara nilai kaedah dan pola perilaku nyata yang bertujuan untuk mencapai kedamaian.

2. Faktor Penegakan Hukum. Fungsi hukum, mentalitas atau kepribadian petugas penegak hukum memainkanperanan penting, kalau peraturan sudah baik, tetapi kualitas petugas kurang baik, ada masalah. Oleh karena itu, salah satu kunci keberhasilan dalam penegakan hukum adalah mentalitas atau kepribadian penegak hukum

3. Faktor Sarana atau Fasilitas Pendukung. Faktor sarana atau fasilitas pendukung mencakup perangkat lunak dan perangkat keras, salah satu contoh perangkat lunak adalah pendidikan. Pendidikan yang diterima oleh Polisi dewasa ini cenderung pada halhal yang praktis konvensional, sehingga dalam banyak hal polisi mengalami hambatan di dalam tujuannya, diantaranya adalah pengetahuan tentang kejahatan elektronik, dalam 
tindak pidana khusus yang selama ini masih diberikan wewenang kepada jaksa, hal tersebut karena secara teknis yuridis polisi dianggap belum siap. Walaupun disadari pula bahwa tugas yang harus diemban oleh polisi begitu luas dan banyak.

4. Faktor Masyarakat. Penegak hukum berasal dari masyarakat dan bertujuan untuk menjaga keamanan dan ketertibandi dalam masyarakat. Setiap warga masyarakat atau kelompok sedikit banyaknya mempunyai kesadaran hukum, persoalan yang timbul adalah taraf kepatuhan hukum, yaitu kepatuhan hukum yang tinggi, sedang, atau kurang. Adanya derajat kepatuhan hukum masyarakat terhadap hukum, merupakan salah satu indikator berfungsinya hukum yang bersangkutan.

5. Faktor Kebudayaan. Berdasarkan konsep kebudayaan, orang begitu sering membicarakansoal kebudayaan. Kebudayaan menurut Soerjono Soekanto, mempunyai fungsi yang sangat besar bagi manusia dan masyarakat, yaitu mengatur agar manusia dapat mengerti bagaimana seharusnya bertindak, berbuat, dan menentukan sikapnya kalau mereka berhubungan dengan orang lain. Dengan demikian, kebudayaan adalah suatu garis pokok tentang perilaku yang menetapkan peraturan mengenai apa yang harus dilakukan, dan apa yang dilarang.

Dihubungkan dengan hasil wawancara dan kenyataan terhadap aparat kepolisian wilayah hukum Payakumbuh dihubungkan dengan faktor-faktor yang mempengaruhi penegak hukum, penulis menyimpulkan yang menjadi faktor-faktor kendala dalam penyitaan barang lalu lintas yang terjadi di kota Payakumbuh.

Berdasarkan wawancara dengan KBO Lantas Polres Payakumbuh Ipda Eldrina Wati, beliau menyampaikan ada beberapa faktor penghambat dalam penyitaan barang bukti pelanggaran Lalu Lintas di Wilayah Hukum Polres Payakumbuh antara lain: 1) Kurangnya jumlah personil satuan lalu lintas jika dibandingkan dengan banyaknya jumlah pelanggaran lalu lintas yang terjadi setiap harinya; 2) Masih banyaknya masyarakat yang belum mengetahui dan paham tentang Undang-undang lalu lintas dan aturan lalu lintas lainnya, sehingga banyak diantara si pelanggar yang tidak terima terhadap pasal maupun sanksi yang ditetapkan oleh pihak kepolisian lalu lintas sehingga terkadang terjadi adu mulut antara petugas dengan si pelanggar; dan 3) Banyak diantara para pelanggar yang berusaha untuk melarikan diri/ kabur saat razia sedang dilaksanakan sehingga dapat memicu dan menyebabkan terjadinya kemacetan ataupun kecelakaan lalu lintas.

\section{Upaya Yang Dilakukan Untuk Mengatasi Faktor Penghambat Dalam Penyitaan Barang Bukti Pelanggaran Lalu Lintas Di Wilayah Hukum Polres Payakumbuh}

Berdasarkan wawancara dengan KBO Lantas Polres Payakumbuh Ipda Eldrina Wati, beliau juga menyampaikan upaya dalam menghadapi faktor penghambat dalam penyitaan barang bukti pelanggaran Lalu Lintas di Wilayah Hukum Polres Payakumbuh antara lain: 1) Adanya penambahan personil satuan lalu lintas di wilayah hukum Polres Payakumbuh dari 45 orang menjadi 65 orang supaya pelaksanaan penyitaan barang bukti pelanggaran Lalu Lintas di Wilayah Hukum Polres Payakumbuh dapat dilaksanakan secara maksimal; 2) Polres Payakumbuh melakukan penyuluhan/sosialisasi tentang tentang Undang-undang lalu lintas dan aturan lalu lintas serta bagaimana berkendara yang baik kepada tokoh masyarakat, pemuka adat, tokoh agama, dan masyarakat serta datang ke sekolah-sekolah sebagai upaya pencegahan agar mereka mengetahui dan paham tentang aturan, dengan demikian diharapkan angka pelanggaran dan kecelakaan lalu lintas di wilayah hukum Polres Payakumbuh dapat berkurang; dan 3) Memberikan tindakan tegas terhadap para pelanggar yang berusaha untuk melarikan diri/ kabur saat razia sedang dilaksanakan sehingga tidak menyebabkan terjadinya kemacetan ataupun kecelakaan lalu lintas.

Selain itu upaya yang dilakukan adalah dengan memberikan arahan arahan dan pelatihan pelatihan kepada personil Lalu Lintas tentang prosedur-prosedur penanganan penindakan dan penyitaan terhadap pelanggaran Lalu lintas di wilayah hukum Polres Payakumbuh polisi. 
Terhadap faktor penegak hukum yakni aparat lalu lintas kota Payakumbuh seringkali dalam menegakkan hukum tidak tegas dalam menegakkan aturan sehingga pada aparat polisi dapat dilakukan penyegaran dengan melakukan pembinaan dan melakukan pelatihan pelatihan tentang tata cara melakukan penanganan,penindakan pelanggaran Lalu Lintas. Faktor sarana dan prasarana, kurangnya sarana dan prasarana pendukung seperti kurangnya rambu-rambu lalu lintas, tidak aktifnya alat pemberi isyarat Lalu mengatasi dengan melakukan perbaikan dan penambahan terhadap rambu rambu oleh aparat yang membidangi mengenai sarana dan prasarana lalulintas yakni instansi perhubungan sehingga masyarakat dapat memahami dan petugas dapat melakukan pengawasan dan penindakan. Faktor Masyarakat hukum itu berlaku pada setiap warga negara, ada kalanya pelanggaran yang terjadi disebabkan kesadaran hukum yang kurang mengakibatkan ketidaktaatan terhadap hukum itu sehingga perilaku melakukan pelanggaran masih cendrung terjadi seperti melewati jalan verboden dan melakukan pelanggaran terhadap alat pemberi isyarat lalu lintas dan kabur pada saat akan ditilang. Untuk mengatai hal tersebut dilakukan sosialisasi, penyuluhan tentang pengetahuan berlalu lintas baik terhadap instansi maupun terhadap mahasiswa, pelajar dan warga masyarakat di kota Payakumbuh.

Indonesia adalah Negara hukum, hal ini sesuai dengan UUD 1945 yang secara nyata menyatakan Indonesia sebagai negara hukum yiatu pada pasal 1 ayat (3) UUD 1945 berbunyi: "Negara Indonesia adalah Negara yang berdasarkan hukum." Selain itu, dalam Penjelasan Umum UUD 1945 tentang Sistem Pemerintahan Negara, dijelaskan bahwa Indonesia adalah negara yang berdasar atas hukum (Rechtstaat) tidak berdasar atas kekuasaan belaka (Machtstaat). Dengan posisi Negara Indonesia sebagai Negara hukum sudah sepatutnya setiap tindakan atau perbuatan yang terjadi diselesaikan secara hukum. Tiap perbuatan atau tindakan hukum dilakukan oleh subjek hukum. Subjek hukum yakni manusia atau masyarakat terkhusus yang dimulai dari lahirnya manusia sampai meninggalnya manusia. Untuk menjamin ketertiban hukum maka diperlukan peran aparat penegak hukum dalam menjalankan hukum itu sendiri demi mencapai tujuan hukum yang berkepastianuntuk mencapai, keadilan, dan kemanfaatan hukum itu sendiri.Akan tetapi masih banyak terjadi kendala dalam penegakan hukum diantaranya penyitaan barang bukti pelanggaran lalu lintas. Untuk mengatasi kendalakendala tersebut dibutuhkan upaya-upaya dalam menghadapi kendala-kendala tersebut. Sebelum masuk ke pokok bahasan, penulis membahas mengenai upaya-upaya dalam mengatasi kendala penegakan hukum. Upaya dalam mengatasi kendala penegakan hukum ialah pengendalian sosial. Pengendalian sosial bertujuan untuk mencapai kedamaian melalui keserasian antara kepastian dengan keadilan.

Dari pernyataan diatas yang sifatnya dapat dikatakan bahwa pengendalian sosial itu dapat bersifat preventif dan represif. Yang mana tindakan Preventif merupakan suatu usaha pencegahakan terhadap terjadinya gangguan-gangguan dan permasalahan permasalahan yang akan terjadi sehingga akan menimbulkan pada keserasian antara kepastian dan keadilan. Sedangkan usaha-usaha yag represip atau dengan kata lain penindakan yang bertujuan mengembalikan keserasian yang pernah mengalami gangguan (Soerjono Soekanto 1990:226). Dalam bahasan penulis, penulis membahas upaya dalam menghadapi kendala dalam penyitaan barang bukti pelanggaran lalu lintas di wilayah hukum Polres Payakumbuh dihubungkan dengan kenyataan yang terjadi melalui hasil penelitian yang peneliti lakukan, penulis menyimpulkan bahwa upaya dalam menghadapi kendala dalam penyitaan barang bukti pelanggaran Lalu Lintas di wilayah hukum Polres Payakumbuh adalah dengan cara preventif atau dengan kata lain melakukan pencegahan.

\section{Penutup}

Berdasarkan pembahasan tersebut di atas, maka penulis telah menarik kesimpulan terkait Pelaksanaan Kewenangan Aparat Kepolisian Dalam Melakukan Penyitaan Barang Bukti Pelanggaran Lalu Lintas Di wilayah Hukum Polres Payakumbuh sebagai berikut: 1) Pelaksanaan kewenangan aparat dalam melakukan penyitaa barang bukti pelanggaran lalu lintas dipolres payakumbuh sudah dilaksanakan sesuai dengan aturan yang berlaku yaitu sesuai 
dengan Undang-Undang Nomor 2 Tahun 2002 Tentang Kepolisian Republik Indonesia Pasal 16 ayat (1) huruf a dan huruf e, Undang-Undang Nomor 22 Tahun 2009 tentang Lalu Lintas dan Angkutan Jalan Pasal 260 ayat (1) huruf d, dan Pasal 38 ayat (1) dan (2) KUHAP, Pasal 40, 39 ayat (1) dan Pasal 41 KUHAP tetapi belum maksimal karena adanya beberapa hambatan dilapangan; 2) Faktor penghambat dalam pelaksanaan penyitaan barang bukti pelanggaran Lalu Lintas di wilayah hukum Polres Payakumbuh antara lain adalah Kurangnya jumlah personil satuan lalu lintas, Masih banyaknya masyarakat yang belum mengetahui dan paham tentang Undang-undang lalu lintas dan aturan lalu lintas lainnya, dan banyaknya para pelanggar yang berusaha untuk melarikan diri/ kabur saat razia sedang dilaksanakan sehingga dapat memicu dan menyebabkan terjadinya kemacetan ataupun kecelakaan lalu lintas; 3) Upaya dalam menghadapi hambatan dalam pelaksanaan penyitaan barang bukti pelanggaran Lalu Lintas di wilayah hukum Polres Payakumbuh adalah Adanya penambahan personil satuan lalu lintas di wilayah hukum Polres Payakumbuh dari 45 orang menjadi 65 orang, Polres Payakumbuh melakukan penyuluhan/sosialisasi tentang tentang Undang-undang lalu lintas dan aturan lalu lintas serta bagaimana berkendara yang baik, dan Memberikan tindakan tegas terhadap para pelanggar yang berusaha untuk melarikan diri/ kabur saat razia sedang dilaksanakan; dan 4) Masyarakat harus bisa memahami peraturan lalu lintas dengan baik, dan seharusnya juga harus dilakukan sosialisi terhadap aturan tentang berlalu lintas, adanya penambahan personil satuan lalu lintas di wilayah hukum Polres Payakumbuh Petugas satuan lalu lintas harus secara kontiniu memberikan tindakan terhadap pelanggar lalu lintas, Adanya penambahan sarana dan prasarana terhadap rambu-rambu lalu lintas dan APIL yang berfungsi agar angak pelanggaran semakin mengekil, Harus adanya penindakan yang tegas bagi pelanggar yang berusaha kabur ketika saat razia.

\section{Daftar Pustaka}

Alfons Loemeu, 2005, Penegakan Hukum oleh Polri, Restu Agung, Jakarta.

Andi Hamzah, 2001, Bunga Rampai Hukum Pidana dan Acara Pidana, Ghalia Indonesia Jakarta.

Bambang Poernomo, 2002, Dalam Asas-Asas Hukum Pidana, Ghalia Indonesia, Jakarta.

Bambang Wardoyo, 2013, Analisis Kewenangan Kepolisian dalam Proses Penyitaan Barang Bukti Pelanggaran Lalu Lintas, Skripsi S1 Fakultas Hukum, Universitas Lampung.

Hartono, 2010, Penyidikan dan Penegakan Hukum Pidana Melalui Pendekatan Progresif, Jakarta, Sinar Grafika.

Jimly Asshiddiqie, 2006, "Pembangunan Hukum Dan Penegakan Hukum Di Indonesia", Makalah pada "Menyoal Moral Penegak Hukum" dalam rangka Lustrum XI FH UGM.

Leden Marpaung, 1991, Unsur-Unsur Perbuatan yang Dapat Dihukum, Sinar Grafika, Jakarta.

M.Karyadi dan R.M. Sosroharjono, 1964, Perundang-undangan Lalu Lintas Jalan di Indonesia, Politeia, Bogor.

Moeljatno, 2002, Azas-Azas Hukum Pidana, Rieneka Cipta, Jakarta,2002.

M.Yahya Harahap, 2005, Pembahasan Permasalahan Dan Penerepan KUHAP, Sinar Grafika, Jakarta.

Ratna Nurul Afiah, 1989, Barang Bukti dalam Proses Pidana, Jakarta, Sinar Grafika

Soerjono Soekanto, 1986, Kesadaran Hukum dan Kepatuhan Hukum,CV. Rajawali , 1986, Jakarta.

Soerjono Soekanto, 1990, Sosiologi Suatu Pengantar, Jakarta, Raja Grafindo Persada. 2004, Faktor-Faktor Yang Mempengaruhi Penegeakan Hukum Cetakan Kelima, Jakarta, Raja Grafindo Persada

Wirjono Prodjodikoro, 2003, Asas-asas Hukum Pidana, PT. Refika Aditama, Bandung. 2012, Tindak-Tindak Pidana Tertentu Di Indonesia, PT. Refika Aditama, Bandung.

Zulkifli Amir, 2014, Analisis Kewenangan Kepolisian dalam Proses Penyitaan Barang Bukti Pelanggaran Lalu Lintas, Skripsi S1 Fakultas Hukum, UIN Alauddin Makassar.

Petunjuk Pelaksanaan dan Teknis Lalu Lintas Pol, Departemen Keamanan Mabes Polri, 1983.

400 Lembaga Penelitian dan Penerbitan Hasil Penelitian Ensiklopedia $\quad$ E-ISSN: 2657-0300

P-ISSN: 2657-0319 